\title{
Open innovation and technology development process: the gap on partnership adoption from a case study perspective
}

\author{
Mauro Caetano ${ }^{a}$, Claudiano Sales Araujob, Daniel Capaldo Amaral', Fábio Müller Guerrinic \\ oFederal University of Goias \\ bEMBRAER \\ University of Sao Paulo
}

e-mails: maurocaetano1912@gmail.com; claudiano@embraer.com.br; amaral@sc.usp.br; guerrini@sc.usp.br

\begin{abstract}
Open innovation is one of the strategies employed by enterprises to optimize innovation processes through the establishment of partnerships in technology development. Despite the importance of open innovation, there have been few studies on application cases or studies that identify practices and tools supporting this strategy. This study firstly aimed at analyzing reference models used in technology development processes (TDP) from the literature. This showed that TDP reference models only superficially address the establishment of partnerships in innovation processes. Then, a similar analysis was carried out with a large enterprise belonging to the aeronautical sector. This analysis identified the company's level of adequacy to open innovation, the benefits and the difficulties resulting from its use. This analysis showed that the enterprise is changing the process of TDP according to open innovation and through two practices of interest: the structuring of teams according to technology maturity and the strategic guidance for encouraging the adoption of partnership in these projects. In addition to new practices, the study identifies challenges for the management of innovation, as the adoption of systematic analysis of partnerships and their impact throughout the TDP, and suggestions for future research.
\end{abstract}

Keywords: innovation management, innovation planning, reference model.

\section{Introduction}

The Technology Development Process (TDP) is a critical success factor in the development of products and in promoting the competitiveness of enterprises. Therefore, promoting the understanding of this process and suggesting tools that can assist in structuring enterprises' TDP reference models, the main goals of this study, may be considered as relevant contributions to this area of knowledge.

Porter (1990) sustains that if an enterprise desires to gain a competitive edge it should be knowledgeable and have access to scientific studies from all over the world concerning its industrial sector. This implies that it needs to interact with different types of organizations and incorporate their knowledge into its innovation processes.

In addition, due to the increasing complexity of technologies embedded in new products, their incorporation depends on greater knowledge than ever and, consequently, on the cooperation among different specialists. This makes the process more complex and their successful adoption more challenging (HUSTON; SAKKAB, 2006). In fact, even mega-corporations - once famous for their self-sufficient R\&D structures and product development processes - find it difficult to master satisfactorily all of their technologies due to the fast pace of today's scientific advancement.

It appears that the practical application of open innovation can provide an adequate answer to this challenge because its main strategy is to deliberately develop new technologies through partnerships with diverse organizations instead of adhering to the classic model (closed innovation), which employs internal R\&D structures (CHESBROUGH, 2006).

The term 'open innovation' has drawn a lot of attention worldwide. In spite of this, the related literature has mainly addressed issues linked to business models and intellectual property.

As shown in the literature review at this study, the theoretical models of TDP identified in the literature (CLARK; WEELWRIGHT, 1993; CLAUSING, 1993; COOPER, 2006; CREVELING; SLUTSKY; ANTIS, 2003) are not adequately suited for open innovation. This can be seen both in the composition of the activities of these models in the reality of a case study of a world-class company in the aeronautics industry that has adapted to the paradigm of open innovation. Cooper (2008), a scholar of product development management, points out that one of 
the challenges that researchers in this area have faced is to develop stage-gate models adapted to the open innovation paradigm.

This study sought to identify the implications of open innovation strategies for technology development management models. Besides carrying out a comparative analysis of the literature from a theoretical model of PDT, it evaluated a real case of an aeronautical enterprise, whose sector has been known to promote, however informally, open innovation because of its degree of internationalization and the complexity of its technologies. Along these lines, this article compares the theory to an enterprise's practical use of it and points future trends of research in order to restructure models of TDP according to the reality of open innovation.

\section{Open innovation}

The strategy adopted by an enterprise for its technology development defines how it may efficiently obtain a competitive edge in the market. Pappas (1984) suggests that an enterprise planning its technologic strategies should follow these steps:

- Evaluate present technologic situation within or without the organization;

- Develop a technologic portfolio in its structure;

- Integrate the organization's different technologic strategies; and

- Define technology investment priorities, thus focusing on the development of technologies that will yield the highest productivity and profitability.

This planning will offer better results if the enterprise expands its search for innovation information and market opportunities by means of external agents located in several parts of the world, i.e., by means of open innovation (CHESBROUGH, 2006; CHESBROUGH; SCHWARTZ, 2007; SCINTA, 2007).

Bearing in mind the concept of technologic strategy, it is possible to define open innovation as a strategy of making use of networks of enterprises (e.g., customers, suppliers and partner enterprises), teaching and research organizations (e.g., universities and research centers) to increase one's innovation capability.

Table 1 shows a summary of the main characteristics and differences between both models presented by Chesbrough (2006).

When correctly implemented, open innovation optimizes the use of tangible or intangible technology resources located within or without the organization (HAINES; SHARIF, 2006). Conversely, neglecting open innovation may have serious implications for the enterprise's financial well-being, since maintaining an internal $R \& D$ structure requires a major mobilization of resources, which in the end may be as costly as sharing knowledge to promote the enterprise's competitiveness (CHESBROUGH, 2003).

Along these lines, Huston and Sakkab (2006) describe the case of Procter \& Gamble, which maintains a considerable structure for technology development as compared to most companies. Nonetheless, this enterprise recognizes that it is difficult to keep updated with the technologies used in its products, which range from basic chemistry to mechanics, electronics and instrumentation. The solution adopted by Procter \& Gamble is to establish R\&D partnerships via open innovation.

In the case reported by Huston and Sakkab (2006), there is a set of initiatives to guarantee a continuous flow of ideas and projects (technologies and products) in partnership with different agents: customers, suppliers, retailers and academic researchers.

In the last years there was a significant increase in the number of enterprises that established R\&D partnerships, contracts with research labs and universities for the development of technologies. This reinforces the importance of open innovation as a tool enterprises should profit from (ELMQUIST; FREDBERG; OLLILA, 2009; SCINTA, 2007).

One of the factors that favor the adoption of open innovation is the establishment of innovation networks, which involve the cooperation among different organizations and draws on strategic alliances as opportunities to advance competitiveness (RYCROFT; KASH, 2004).

Table 1. Main differences between closed and open innovation.

\begin{tabular}{|l|l|}
\hline \multicolumn{1}{|c|}{ Closed innovation } & \multicolumn{1}{|c|}{ Open innovation } \\
\hline $\begin{array}{l}\text { Expert knowledge needed for the new technology is found at the } \\
\text { enterprise. }\end{array}$ & $\begin{array}{l}\text { Not all the expert knowledge needed for the new technology can be } \\
\text { found at the enterprise. Lacking knowledge is sought outside the } \\
\text { organization. }\end{array}$ \\
\hline Internal R\&D specialists find out, develop and deliver solutions. & $\begin{array}{l}\text { External R\&D specialists may create significant values, and internal } \\
\text { R\&D selects them. }\end{array}$ \\
\hline $\begin{array}{l}\text { Enterprise wins if it is the first to discover, if it comes up with the best } \\
\text { ideas, if it the first to commercialize something. }\end{array}$ & $\begin{array}{l}\text { Building a superior business model is oftentimes better than being the } \\
\text { first enterprise to take the market. }\end{array}$ \\
\hline $\begin{array}{l}\text { The enterprise's intellectual properties must be protected from } \\
\text { competitors. }\end{array}$ & $\begin{array}{l}\text { Competitors should be allowed draw on the enterprise's intellectual } \\
\text { properties, and the enterprise should to make use of others' intellectual } \\
\text { properties and improve its business model. }\end{array}$ \\
\hline
\end{tabular}


Several benefits may be obtained by open innovation through networks, such as agility in reacting to environmental changes and market opportunities, complementariness of different partners' competencies, optimization of resources, and generation of ideas as the basis for innovation (CAMARINHA-MATOS; AFSARMANESH, 2003).

Dittrich and Duysters (2007) consider open innovation to be a complex network of relationships with other organizations that serves diverse purposes at different moments and point to the importance of establishing partnerships as a technologic strategy in times of change.

Although open innovation is presented as an important tool, it should be reminded that there will always be some level of closed innovation within organizations and that each industry sector or enterprise deals with innovation differently. The reason is that some technologic information must remain restricted, as is the case of the sector under consideration. In the aeronautical sector, the enterprises' competitiveness may be compromised if critical information is shared with partners (CHRISTENSEN; OLESEN; KJÆR, 2005).

Despite the auspiciousness expressed by the academy with respect to open innovation, an important issue remains to be discussed by professionals and scholars: how to include practices and tools to assist in the introduction of adequate levels of open innovation so as to have a positive impact on the enterprises' innovation performance.

It is believed that one solution to fit with the open innovation in organizations is related to the restructuring of TDP in order to consider the adoption of partnerships in certain stages of the process.

\section{Technology development process}

Many technology development models may be found in the literature (CLARK; WEELWRIGHT, 1993; CLAUSING, 1993; COOPER, 2006; CREVELING; SLUTSKY; ANTIS, 2003; WHITNEY, 2007; SCHULZ et al., 2000). Besides, these models address technology development as a process, with well defined stages and decisions, which enables the identification of gaps leading to the establishment of partnerships.

Whitney (2007) presents a set of technology development tools ranging from identification and selection of opportunities to development and evaluation of the final concept proposed for a given technology. However, the applicability of this author's model presented is restricted to the organization's internal processes, which places it in the closed innovation category.

The technology development model presented by Schulz et al. (2000) mainly focuses on business strategies, their deployment, analysis and selection, and the transference of a given technology to product development process (PDP). The authors provide a model in which organizations must have not only a product portfolio, but a technology portfolio based on the requirements of every product in the product portfolio. The study also contributes towards overcoming the organization's internal cultural barriers concerning the transference of technology to PDP.

With respect to the models by Creveling, Slutsky and Antis (2003) and Cooper (2006), it is possible to say that the former presents a TDP model and a PDP model in a integrative way whereas the latter presents important considerations that concern the goal of this study, e.g., the insertion of open innovation into innovation processes, done by the author via the stage-gate model.

One of the TDP models presented in the literature by Cooper (2006) is shown in Figure 1, whose activities are divided into three moments, which the author calls "stages": I) Project Scoping : where planning is mapped out, taking into account the business features; II) Technical Assessment: where the probabilities of developing the idea are demonstrated by means of analysis of partnerships and impacts of this technology; and III) Detailed Investigation: where, after having defined the technology scope, experiments are implemented and the technology values are defined for the organization.

These stages are preceded by three gates or decision steps, whose main characteristics are:

- Gate 1: the organization's top administration and R\&D leaders verify whether a given idea merits development effort and investment followed by formulation of project and scope;

- Gate 2: the same actors as those at Gate 1 determine qualitatively the limitations of the project scope, which will enable the analysis of existing technology (technological evaluation);

- Gate 3: the same actors from Gate 2/Gate 1 and other leaders involved in the business analyze the project viability using the information gathered at Gates 1 and 2, which will support the technological investigation.

In addition to these three gates that precede the three stages of this model, there is a fourth Gate (Gate 4) involving

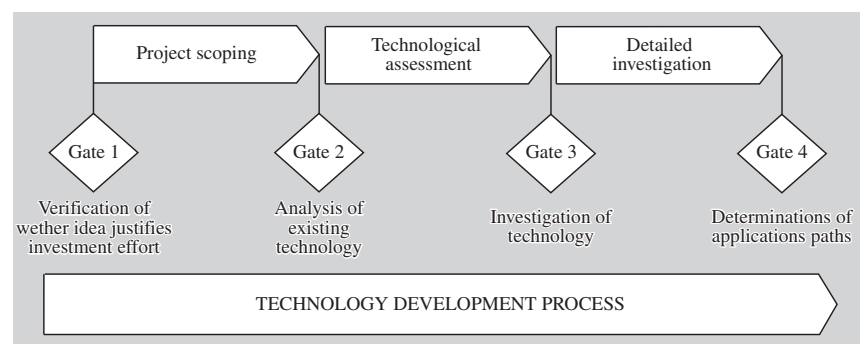

Figure 1. TDP model elaborated according to the stages proposed by Cooper (2006). 
the same actors as those at Gate 3 and other people interested in the commercial results of the projects. This gate is immediately after stage 3 and closes the proposed model. At Gate 4 the product development process to which a given technology will be applied is determined and TDP and PDP are integrated.

Among several other models of TDP available in the literature some relevant studies propose which specific activities are necessary for the development of technology. The results presented by Clark and Weelwright (1993), Clausing (1993), Cooper (2006) and Creveling, Slutsky and Antis (2003) are the most detailed in terms of activities and phases of TDP and therefore were considered relevant to this study. The Figure 2 presents a theoretical model of TDP with a set of these stages that have been grouped by similarity from the propositions of these authors.

The TDP presented at the Figure 2 contains six different stages which start from an idea and finish at the technology developed and ready to be integrated in a product, service or process development process (CAETANO; AMARAL, 2011b). These stages can be oriented from the market and technology trends based on internal competencies at the organization. These stages are realized with the follow activities:

- Invention: define the enterprise' strategic planning, determining technology strategy, identify the voice of technology (basic and applied research), identify the voice of the consumer (market research), idea generation;

- Project Scope: develop project scope, mapping future plans, conducting research literature, conduct patent searches, identifying opportunities;

- Technology concept development: identify the potential of the idea under certain conditions by preliminary experiments, identify necessary resources and solutions to the gaps identified, designing product platforms, QFD to create a technology (technology needs), conduct benchmarking of available technology, develop network of partners, defining features of the new technology, identify the impact of technology in the company, analyze documents and generate technology concept;

- Technology development: select and develop concept of superior technology, define commercial products

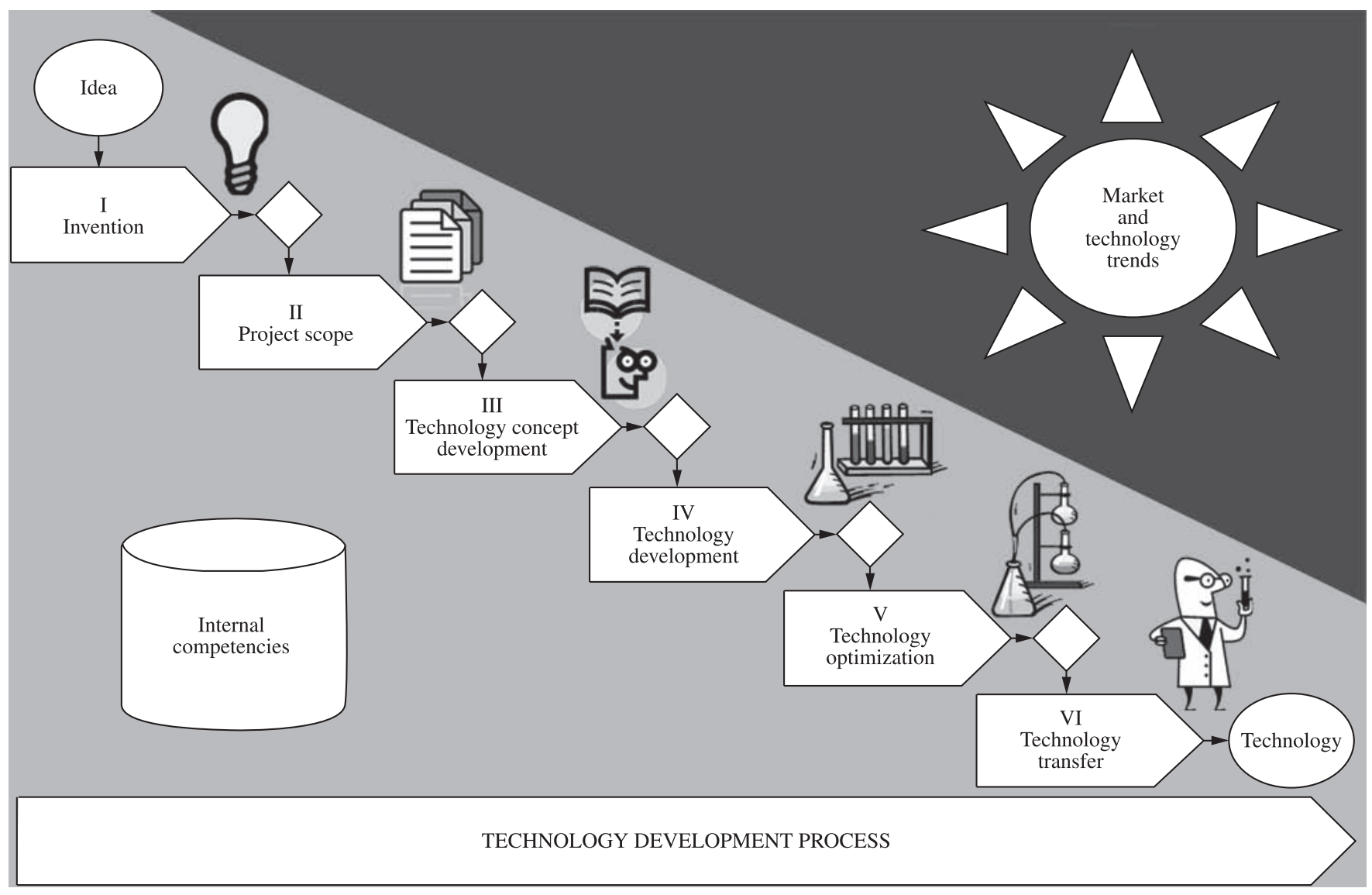

Figure 2. TDP theoretical model elaborated by the authors according to the stages proposed by Clark and Weelwright (1993), Clausing (1993), Cooper (2006) and Creveling, Slutsky and Antis (2003). 
and processes possible, decompose system functions into sub functions, define system architecture, use mathematical models that express the ideal function of technology, develop and test prototype, identify market impact and manufacture of these possibilities, prepare to implement the business case, identify and evaluate critical parameters;

- Technology optimization: optimize technology from its critical parameters, analyze factors that may result in platforms, develop subsystems of the platform, implement and optimize experiments, analyze data from experiments;

- Technology transfer: design a platform, integrate the subsystems, performance testing of the system, define criteria for selection of technology.

According to the Figure 2 and these activities from each of these stages, it is possible to observe that the development of technology starts from the strategic planning of the organization, along with defining the technology strategies and idea generation make the initial invention in the TDP. In sequence are conducted the stages of project scope, technology concept development, development and optimization of technology and, finally, the stage of technology transfer.

It should be noted that these activities of the TDP only in the third phase of this theoretical model, or after being held about $40 \%$ of the proposed activities in the process, the model proposes the creation of networks of partners, which requires an analysis of the TDP in accordance with the paradigm of open innovation.

\section{Open innovation and TDP}

The analysis of the literature on open innovation - as well as on related TDP models - revealed that its main characteristics are the complementary use of external sources of innovation complementarily to the enterprise's core competencies as a fundamental part of the technology development strategy. A product usually consists of different technologies that make up a technologic platform. Therefore, open innovation presupposes that part of this platform should be developed in partnership with different actors, such as research institutes, suppliers and customers (CHESBROUGH, 2006).

Therefore, the planning stage and the stages of technological sourcing, idea development, tests and validation of technologies should be carried out jointly by the partners, as presented by Caetano and Amaral (2011a) considering the partner selection on technology roadmapping. The technology development model should encompass stages and tools to plan, control and validate the technologies developed collectively. It should also provide for more powerful coordination, i.e., the orchestration of concurrent technology projects to lessen the risks caused by external involvement.

WHITNEY's model (2007), in turn, describes TDP as constrained by the resources that are made available to the R\&D team. The effects on the enterprises' TDP caused by transposing these internal organizational limits have not yet been reported. Still, activities such as research, SWOT analysis of technologies and testing could be optimized by open innovation because partners could share the risks associated with the development of new technologies.

On the other hand, Schulz's (2000) model considers in its first stage (Technology Integration Strategy) that the decision on what to invest (e.g., partnerships, licensing, invention and acquisition of technologies) derives from market analyses and technological perspectives. However, this model does not take into account the utilization of external resources to improve TDP performance. Besides, there seems to be a bottleneck concerning the cultural barriers presented by the authors when integrating the technology into PDP. These barriers would draw more concentration if open innovation was employed by the organization in consideration of different organizational cultures.

The model proposed by Creveling, Slutsky and Antis (2003) is deficient in that it presupposes closed development, i.e., it is entirely developed within a single organization. Although this model comprises TDP and PDP as well as tools for statistical analysis and process control, it does not consider partnerships with external agents as a strategy to optimize both processes. Yet, this model pays special attention to technology validation. This is a fundamental step towards the concept of open innovation, since it promotes the integration of technologies developed through partnerships and products that will reach the market.

On the other hand, Cooper's (2006) model attaches importance to the establishment of partnerships in its second stage (Technology Evaluation). Nevertheless, it does not present previous activities such as planning for partnerships or justifying the need for partners, i.e., however present, the development of TDP partnerships is not specifically dealt with by this model.

This deficiency of technology development models in addressing open innovation was corroborated by a recent study by Cooper (2008). This study suggests that enterprises should adapt to market changes and employ open innovation in their stage-gate systems because it provides opportunities to improve the performance of new product development processes.

In sum, it may be remarked that the technology development models identified in the literature fail to show market applications as well as to consider the establishment of partnerships in their stages.

The lack of theoretical models that comprise open innovation does not imply that there are not management 
practices capable of sponsoring this strategy. There are enterprises from several sectors that have been working within this paradigm for many years. Therefore, in order to identify research themes, it was considered important to analyze real-life problems in technology development models of enterprises that had experience in using it.

Subsequently, it was decided to analyze a large multinational enterprise in the aeronautical sector, one of the largest world aeronautical industries belong to a technologyintensive sector among those that invest the most in R\&D (FRENKEN, 2000; WOLFF, 2004). This enterprise clearly distinguishes between TDP and PDP, which is something that enterprises, or even authors, seldom do. Acknowledging this difference facilitates the analysis and enables better communication between academics and managers and better management of $R \& D$ resources and risks related to new technologies and products (ELDRED; MCGRATH, 1997; LAKEMOND; JOHANSSON; MAGNUSSON, 2007).

\section{Method}

The case study was uses to analyze the technology development model adopted by an aeronautical enterprise and compare it to those found in the literature, so as to identify the presence of specific open innovation management practices and the major problems of the models. The use of a case study method was necessary because it enables the investigation of phenomena in real contexts, thus allowing the transposition of existing limits from theoretical models to practical models (YIN, 1994). To this end, after the selection of the enterprise, the departments and key people related to its innovation processes were identified and asked to participate in the research. Two specialists from the enterprise's technology development department that presently work as managers of technology development projects and competitive technology intelligence were interviewed.

The focus of this study is a large company in the aeronautics industry which, besides being one of the biggest players in this industry, was adopted as an object of study because of the characteristic of its innovative products, which requires constant improvement in their practices innovation management.

The interviews followed a pre-established script that aimed, based on theoretical models, found in the literature from a bibliographical review (BRERETON et al., 2007), at identifying the enterprise's prevalent TDP characteristics. As the enterprise's model was being disclosed, the specialists were questioned about the establishment of partnerships and its impacts on the enterprise's innovation management process. The starting point for the identification of open innovation practices in the company was the theoretical model presented in Figure 2.

\section{Results}

The TDP adopted by the enterprise aims at promoting its internal capability needed for the development of future products, i.e., there is a clear distinction between how to do (technology) and what to do (product). The enterprise's TDP assumes the principles of technology stage-gate. The technological guidelines presented here concern technological projections in that the enterprise thinks about and plans for the future, as described by Balaguer et al. (2007).

At Gate 1 the enterprise seeks to identify future scenarios, i.e., it exerts a lot of effort to identify market trends and research carried out by chief actors of this sector. This activity is performed mainly by the group of people that work with competitive market intelligence at the enterprise.

At the same time, the competitive technological intelligence group seeks to identify scenarios in light of technological trends and possible products to be developed. Both groups elaborate documents known as technological guidelines. Subsequently, a third group of people, the competitive intelligence service, integrates the technological guidelines previously elaborated and establishes development priorities so that the technologies to be developed meet the greatest possible number of guidelines. The end product of this stage is the consolidation of technological guidelines - Gate 1 .

At Gate 1 a list of technological priorities to be developed and their relevance are defined. At this point a first analysis of the technology readiness level of each one of them is performed as well (MANKINS, 1995). The list of technological priorities is submitted to Gate 2 .

If a given technological priority has a low TRL, i.e., a low maturity level, a prospection project should be completed prior to the technology project itself. The goal of the prospection project is to raise the level of internal knowledge on the technology in question in order to inform the enterprise's decision-makers on whether an entire technology project should be accomplished. The projects and prospection are carried out by small teams ( 3 to 4 people), with reduced scope, deadline and budget, and usually without the participation of external partners.

On the other hand, if the prioritized technology has a satisfactory maturity level or the prospection project has shown the new technology to be viable, the technology project is carried out in its entirety. From this stage on partnerships are projected and established to develop the technology. This stage begins with the elaboration of a project charter by the team of people who have its description, goals, partnership strategies and premises, names of possible partners, financing strategies and possible sources, scope, WBS, deadlines, macro-chronogram, deliveries and budget. This document, termed as PAM 
(Project Activation Memorandum), is submitted to the enterprise's CEOs for analysis - Gate 3.

When PAM has been approved, the stage of execution and control of activities included in the project begins. This is where activities such as the establishment of partnerships and contracts, submission of financing proposals to external agents, in-depth analysis of patents take place up to the implementation of the technology developed in the enterprise's PDP. The process in this stage demands more work, time and investment, lasting up to four years in some cases, depending on the complexity of the technology and scope of the project. The Figure 3 presents the TDP from the enterprise.

As regards the establishment of partnerships by the enterprise, it is important to underline that it is conditioned by the amount of available resources as upon the establishment of co-development contracts there are teams supervising the technology development activities. Controlling these partnerships demands financial subsidizing.

Despite the fact that the enterprise masters most technologies embedded in its products, 30 to $60 \%$ of the content of the technologies developed in its projects come from outside through partnerships or service contracts, which demonstrates that it makes intense use of $R \& D$ partnerships.

After comparing two projects done by the enterprise, Project $\mathrm{A}$ and $\mathrm{B}$, it was possible to gather relevant data regarding its use of partnerships. Project A was carried out from 1993 to 1996 and involved 4 partners and 350 suppliers. Project B took place between 1998 and 2002 and involved more partners, 16, and fewer suppliers, just 22. The increased quantity of partners and reduced number of suppliers may be attributed to the fact that the enterprise assigned more technical responsibility to partners, who, in turn, managed a larger number of suppliers. This sort of initiative is essential if the enterprise is to share the management of the innovation.

There are no formal criteria for the selection of TDP partners, but it is estimated that $80 \%$ of partner requisites refer to their attested technical competence and the remaining $20 \%$ to their consistent disposition and interest in partnerships. Yet, the enterprise's internal experience has

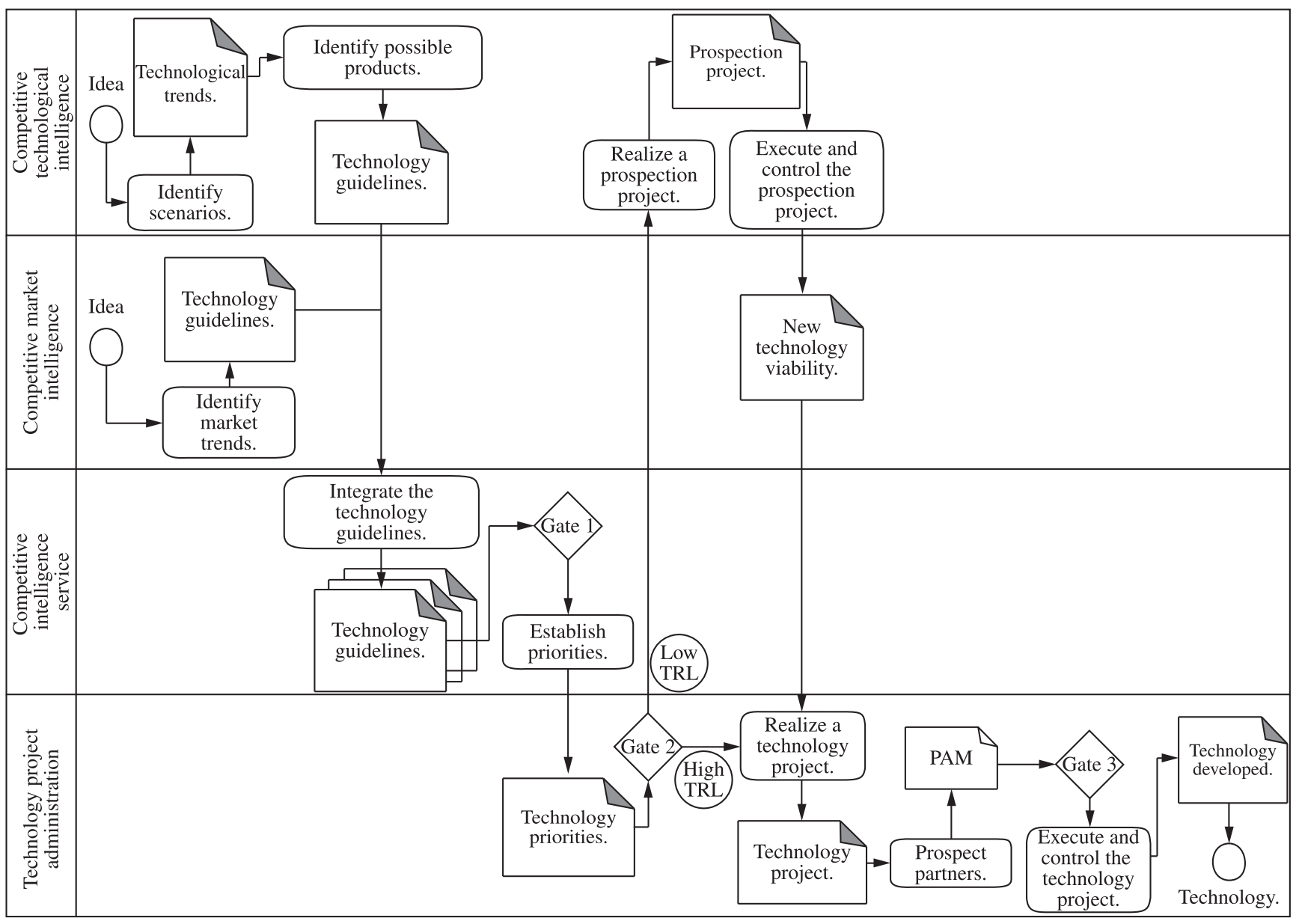

Figure 3. TDP from the enterprise. 
shown that the latter should have a greater weight when selecting partners.

Partner evaluation indicators comprise, besides meeting objectives, chronograms and scope pre-established by the co-development contract, the association with the level of new technology adopted in future airplanes, reduction of costs and increase in efficiency of products made by the enterprise.

The description of the TDP model presently adopted by the enterprise under consideration shows that partnership establishment activities are only carried out after Gate 3, once PAM has been approved, i.e., when the technology is not considered mature and requires a prospection project, the model barely addresses open innovation. This is believed to be a result of the enterprise having scarce knowledge about the technology at this stage of the process, about the main players related to this technology or even about other potential organizations interested in the same technology. Finally, the prospection projects must be carried out swiftly, which would be unviable if there were partnerships during this stage, especially due to the intrinsic difficulties in establishing technological partnership contracts, particularly those that involve still incipient technologies. On the other hand, it is believed that carrying out partnership prospection at this stage could lead to the identification of other enterprises or institutions of great relevance and common value in the joint development of technologies.

Indeed, as pointed out by Cooper (2008), a TDP re-adaptation to address open innovation should be performed early on at the discovery stage of the new technology, when enterprises should, besides identifying customers' needs that should be met, identify young enterprises, inventors, small enterprises or other external resources that can become partners.

In the case in question, these activities may be carried out at the stage of identification of technological guidelines, since they would be in the beginning of the technology development process and could point to the best use of innovation strategies. The partners could be selected according to certain criteria previously established by the company, as confidence, non-competing goals, market expertise, experience in cooperation, experience in innovation, familiarity in terms of reputation and friendship, honesty, motivation and interest in partnerships and cultural compatibility (ANDERSON; NARUS, 1990; BOSCH-SIJTSEMA; POSTMA, 2009; BSTIELER, 2006; BRUCE; LEVERICK; LITTLER, 1995; ENG; WONG, 2006; KALAIGNANAM; SHANKAR; VARADARAJAN, 2007; SHERWOOD; COVIN, 2008).

\section{Conclusion}

The first contribution of this study is to show, despite its relevance, that few authors have devoted research efforts to identify practices related to adopting open innovation. This study also identified that the few theoretical models that take open innovation into account do not advance solutions or tools for the implementation of this strategy, regardless of some authors acknowledging that there are enterprises that have changed their processes to accommodate open innovation.

Along these lines, this study enabled the identification of some factors associated with the technology development process (TDP) that can be improved by the adoption of open innovation. The structured presentation of the study based on the relationship between these two topics, through the analysis of theoretical models and a practical case, constitutes its main contribution.

This study also detected that models found in the literature fail to make use of TDP partnerships, which suggests that future research should be carried out in the direction of proposing new tools for the complete development of technologies in the era of open innovation.

The case analyzed is an indication that the worldclass companies are adapting the models of technology management needs facing the new paradigm of open innovation. The company studied, for example, restructured PDT interesting practices. The adoption of different team structures as the maturity level of technology and the systematic evaluation of partnerships are some of the practices that need to be better studied by the academy.

The advantages obtained by the enterprise in question after implementing open innovation strategies in technological development, such as shared risks/opportunities and joint technological competencies, are some of the elements that make it one of the most successful aeronautical enterprises on the world. Nevertheless, it should be pointed that there are some risks in establishing partnerships, as when partners have different priorities as regards the time spent in technology development, which may result in incompatible deadlines. Therefore, it is sensible to take into account, upon establishing partnerships, not only the prospective partners' technological competencies but also extra-contract criteria such as matching deadlines, expectations and predisposition for cooperative work.

The analysis of the TDP models presented in the literature as well as of the model adopted by the enterprise evidences the need for adoption of partnership not just on stage planning technology, but also throughout all TDP. It can subsidize the themes for future research.

\section{Acknowledgements}

National Council for the Improvement of Higher Education - CAPES, Factory of Millennium Institute IFM, National Council for Scientific and Technological Development - CNPq, The State of Goias Research Foundation - FAPEG and the enterprise focus of this study. 


\section{References}

ANDERSON, J. C.; NARUS, J. A. A Model of distributor firm and manufacturer firm working partnerships. The Journal of Marketing, v. 54, n. 1, p. 42-58, 1990. http://dx.doi. org/10.2307/1252172

BALAGUER, D. L. et al. Technological prospective as a driver for innovation in high-complexity products. In: MACK, T. C. (Org.). Hopes and Visions for the 21st Century. Bethesda: World Future Society, 2007.

BOSCH-SIJTSEMA, P. M.; POSTMA, T. J. B. M. Cooperative innovation projects: capabilities and governance mechanisms. Journal of Product Innovation Management,v. 26, n. 1, p. 58-70, 2009. http://dx.doi.org/10.1111/j.15405885.2009.00334.X

BSTIELER, L. Trust formation in collaborative new product development. Journal of Product Innovation Management, v. 23, n. 1, p. 56-72, 2006. http://dx.doi. org/10.1111/j.1540-5885.2005.00181.x

BRERETON, P. et al. Lessons from applying the systematic literature review process within the software engineering domain. Journal of Systems and Software, v. 80, p. 571-583, 2007. http://dx.doi.org/10.1016/j.jss.2006.07.009

BRUCE, M.; LEVERICK, F.; LITTLER, D. Complexities of collaborative product development. Technovation, v. 15, n. 9, p. 535-552, 1995. http://dx.doi.org/10.1016/01664972(95)96584-G

CAETANO, M.; AMARAL, D. C. Roadmapping for technology push and partnership: a contribution for open innovation environments. Technovation, v. 31, p. 320-335, $2011 \mathrm{a}$. http://dx.doi.org/10.1016/j.technovation.2011.01.005

CAETANO, M.; AMARAL, D. C. Strategic innovation planning and partnerships: aligning market, products/services/ processes and technologies. In: ISPIM INNOVATION SYMPOSIUM: Managing Innovation for Sustained Productivity: Creating Advantage and Resilience, 4., 2011, Wellington. Proceedings... Wellington, 2011b.

CAMARINHA-MATOS, L. M.; AFSARMANESH, H. Elements of a base VE infrastructure. Computers in Industry, v. 51, p. 139-163, 2003. http://dx.doi.org/10.1016/ S0166-3615(03)00033-2

CHESBROUGH, H. The era of open innovation. MIT Sloan Management Review, v. 44, n. 3, 2003.

CHESBROUGH, H. Open innovation: the new imperative for creating and profiting from technology. Boston: Harvard Business School Press, 2006.

CHESBROUGH, H. W.; SCHWARTS, K. Innovating business models with co-development partnerships. Research Technology Management, v. 50, n. 1, 2007.
CHRISTENSEN, J. F.; OLESEN, M. H.; KJÆR, J. S. The industrial dynamics of open innovation - evidence from transformation of consumer electronics. Research Policy, v. 34, 2005.

CLARK, K.; WHEELWRIGHT, S. C. Managing new product and process development: text and cases. New York: Free Press, 1993.

CLAUSING, D. Total quality development: a step-by-step guide to world-class concurrent engineering. New York: American Society of Mechanical Engineers, 1993.

COOPER, R. G. Managing technology development projects. Research Technology Management, v. 49, n. 6, 2006.

COOPER, R. G. Perspective: The Stage-Gate ${ }^{\circledR}$ idea-to-launch process-update, what's new, and nexgen system. Journal of Product Innovation Management, v. 25, p. 213-232, 2008. http://dx.doi.org/10.1111/j.1540-5885.2008.00296.x

CREVELING, C. M.; SLUTSKY, J. L.; ANTIS, D. Design for six sigma: in technology \& product development. New Jersey: Prentice Hall PH, 2003.

DITTRICH, K.; DUYSTERS, G. Networking as a means to strategy change: the case of open innovation in mobile telephony. Journal of Product Innovation Management, v. 24, 2007.

ELDRED, W.; MCGRATH, M. E. Commercializing new technology I. Research Technology Management, v. 40, p. 41-47, 1997.

ELMQUIST, M.; FREDBERG, T.; OLLILA, S. Exploring the field of open innovation. European Journal of Innovation Management, v. 12, n. 3, p. 326-345, 2009. http://dx.doi. org/10.1108/14601060910974219

ENG, T.Y.; WONG, V. Governance mechanisms and relationship productivity in vertical coordination for new product development. Technovation, v. 26, n. 7, p. 761-769, 2006. http://dx.doi.org/10.1016/j.technovation.2004.10.015

FRENKEN, K. A complexity approach to innovation network: the case of the aircraft industry (1909-1997. Research Policy, v. 29, 257-272, 2000. http://dx.doi.org/10.1016/ S0048-7333(99)00064-5

HAINES, J. D.; SHARIF, N. M. A framework for managing the sophistication of the components of technology for global competition. Competitiveness Review 16, n. 2, 2006.

HUSTON, L.; SAKKAB, N. Connect and develop: inside Procter \& Gamble's new model for innovation. Harvard Business Review, p. 61-66, 2006.

KALAIGNANAM, K.; SHANKAR, V.; VARADARAJAN, R. Asymmetric new product development alliances: win-win or win-lose partnerships?. Management Science, v. 53, n. 3, p. 357-374, 2007. 
LAKEMOND, N. et al. Interfaces between technology development, product development and production: critical factors and a conceptual model. International Journal of Technology Intelligence and Planning, v. 3, n. 4, p. 317-330, 2007. http://dx.doi.org/10.1287/ mnsc. 1060.0642

MANKINS, J. C. Technology readiness levels. Office of Space Access and Technology, NASA, 1995.

PAPPAS, C. Strategic management of technology. Journal of Product Innovation Management, v. 1, p. 30-35, 1984. http://dx.doi.org/10.1016/S0737-6782(84)80040-5

PORTER, M. E. The competitive advantage of nations. New York: The Free Press, 1990.

RYCROFT, R. W.; KASH, D. E. Self-organizing innovation networks: implications for globalization. Technovation, v. 24, p. 187-197, 2004. http://dx.doi.org/10.1016/S01664972(03)00092-0
SCHULZ, A. P. et al. Development and integration of winning technology as key to competitive advantage. Systems Engineering, v. 3, n. 4, 2000. http://dx.doi.org/10.1002/15206858(2000)3:4\%3C180::AID-SYS2\%3E3.0.CO;2-H

SCINTA, J. Industrial research institute's R\&D trends forecast for 2007. Research Technology Management, v. 50, n. $1,2007$.

SHERWOOD, A. L.; COVIN, J. G. Knowledge acquisition in university-industry alliances: an empirical investigation from a learning theory perspective. Journal of Product Innovation Management, v. 25, p. 162-179, 2008. http://dx.doi.org/10.1111/j.1540-5885.2008.00292.x

WHITNEY, D. E. Assemble a technology development toolkit. Research Technology Management, 2007.

WOLFF, M. F. Accelerate radical innovation-now! Research Technology Management, 2004.

YIN, R. K. Case study research: design and methods. California: SAGE, 1994. 